[5] M. González-Morín, M. Barrera-Niebla and M. Pérez-Sánchez, Journal of Electroanalitycal Chemistry, 411 (1996) 1.

[6] K.B. Oldham and J. Spanier, The Fractional Calculus, Academic Press, New York (1974).

[7] J. Spanier and K.B. Oldham, An Atlas of Functions, Hemisphere, Washington, DC, and Springer, Berlin (1987).

[8] A.M. Bond and K.B. Oldham, J. Electroanal. Chem., 158 (1983) 193

[9] K. B. Oldham and J. C. Myland, Fundamentals of Electrochemical Science, Academic Press, San Diego (1994)

[10] M. González-Morín, Tesina de Licenciatura, Universidad de La Laguna, 1993.

[11] M. Barrera-Niebla, M. González-Morín and M. Pérez-Sánchez, An. Quim., 89 (1993) 493.

[12] A.J.Bard and L.R.Faulkner, Electrochemical Methods, John Wiley and Sons, 1980 .

\section{Application of Karl Fischer's Method to materials that only release water at high temperatures}

Marta E. Themudo', Aquiles A Barros ${ }^{2}$ and Margarida Bastos ${ }^{2}$

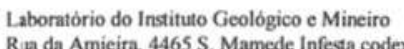

Abstract

The present work describes the development of a new experimental set-up to allow determination of water in solid materials that can not be analysed by the traditional Karl Fischer's coulometric titration, as they are not soluble in Karl Fischer's solution and they only release water at high temperatures.

For this purpose, a new tubular oven was designed and tested, where the temperature can be raised up to $1000{ }^{\circ} \mathrm{C}$, which can be coupled to a Karl Fischer Coulometer. Different geological samples were tested, and the results were crossed with other traditionally used methods for this type of determinations.

\section{Introduction}

The determination of the water content of some materials is very important, both from the point of view of their production and commercialisation and for the study and characterization of their chemical and physical properties.

The present work focus water determination in different geological materials. The traditional method for the determination of the total water content in rocks is the Penfield's Method [1]. Nevertheless, it is considered a method of low precision and low accuracy, as it is biased by other volatile components of the sample, that will be treated as water by the method. 
The adaptation of the traditional Karl Fischer's coulometric method [2] here described arose from the need to develop a method to ascertain the validity and limitations of the Penfield method.

The chemical equation that describes the reaction in the coulometric cell is [3]:

$$
\mathrm{I}_{2}+\mathrm{SO}_{2}+3 \mathrm{RN}+\mathrm{CH}_{3} \mathrm{OH}+\mathrm{H}_{2} \mathrm{O} \rightarrow 2 \mathrm{RNHI}+\mathrm{RNSO}_{4} \mathrm{CH}_{3}
$$

where $\mathrm{R}$ is an alquil, cicloalquil, aril or acil function of the solvent.

The quantitative determination of the water content is thus based on the reaction of $\mathrm{H}_{2} \mathrm{O}$ with an equivalent amount of $\mathrm{I}_{2}$ [4]. In this coulometric technique, the iodine necessary for the reaction is produced by the anodic oxidation of iodide, as:

$$
2 \mathrm{I}^{-} \rightarrow \mathrm{I}_{2}+2 \mathrm{e}^{-}
$$

Since iodine is consumed as long as there is water present, an excess of iodine will indicate the end-point of the titration, detected as a sudden drop in the potential difference.

Water contents up to a maximum of $5-10 \mathrm{mg}$ water can be determined in a short time (circa 10 minutes). This method is particularly useful for samples of low water content $(10 \mu \mathrm{g}-10 \mathrm{mg})$, i.e. to work in the ppm range. As the coulometric titration is an absolute method, it does not require calibration [5]. All this makes it a simple, fast and accurate technique.

The Karl Fisher method has been widely used for the determination of water in different materials that react directly, or dissolve, in the Karl Fischer solution [6]. For these, the method is fast and simple. In cases like the one we did study [7,8,9], there is the need to introduce an oven, so that the water can be liberated from the sample, before being titrated in the cell. This implies adaptations to the original coulometric instrument, and a number of new variable had to be studied and optimised. An oven was designed for the present purpose, which was tested and modified throughout the work.

\section{Experimental Procedure}

A Karl Fischer Coulometer $652 \mathrm{KF}$, Methrom, was used for the water determinations. The flux control for the carrying gas was from Key Instruments. The tubular oven that was designed for this work can be seen in figure 1, and the scheme of the total experimental set-up in figure 2 .

In all cases a Mettler analytical balance $( \pm 0.0003 \mathrm{~g})$ was used.

As drying agents, magnesium perchlorate (Merck, p.a.), sulfuric acid (Merk, p.A.) and molecular sieves (Merck, 0.4 and $1.0 \mathrm{~nm}$ ) were used.

The cell components were dried in an oven at $70^{\circ} \mathrm{C}$, and the more delicate parts with a manual air drier. After this, the cell was charged with $100 \mathrm{ml}$ of Hydranal - Coulomat A (Riedel-de Haën) and immediately closed. The cathodic compartment was filled with about $5 \mathrm{ml}$ of Hydranal - Coulomat C (Riedel-de Haën). After this the system was turned on, and allowed to dry and stabilize.

The addition of the solid sample can be made directly (in direct titration) - in this case it was weighed on a weighing spoon, covered with parafilm, and added quickly to the cell through one of the openings. In the cases where this was not possible, a dried sample holder in ceramics was weighed with the sample and was quickly introduced in the oven at the desired temperature. The carrier gas, nitrogen (Air Liquide, N45 and N60) was turned on, and connected to the measuring cell as depicted in figure 2 . In this case, a blank experiment was performed before each experiment, in the same conditions as the measuring experiment. The amount of sample to be added had to be adjusted to the water content of the sample.

The results are presented in water percentage, defined as

$$
\% \mathrm{H}_{2} \mathrm{O}=\frac{\text { Mass of titrated water }}{\text { Mass of sample }} * 100
$$

\section{Results and Discussion}

Different types of experiments were performed which will now be described separately.

\section{- Determination of the water content of the atmospheric environment}

This experiment was performed in order to quantitate the environment humidity and to test the instrument sensitivity for amounts of water of this order of magnitude. A syringe was filled with air, and injected into the measuring cell. The addition of $1 \mathrm{ml}$ of air was found to have water amounts between 0 and $13.8 \mu \mathrm{g}$, depending on the 
atmospheric humidity conditions. This result shows that extreme care must be used on sample management, as variation in the degree of humidity of the laboratory can introduce a significant error in the determinations.

\section{- Accuracy test}

To check the instrument performance in terms of accuracy, weighed samples of distilled water, in the range $4 \mathrm{mg}-30 \mathrm{mg}$, were injected into the measuring cell. The results present a maximum relative error of $1.6 \%$, indicating a good accuracy.

\section{- Precision tes}

For the precision test (repeatability) two chemicals were used: acetone (Merck, p.a.) and N,N-Dimethylformamide (Merck, p.a.). Samples were taken with a carefully dried 500 $\mu \mathrm{l}$ Hamilton syringe (gas tight), and small amounts were injected into the measuring cell. In each measurement the syringe was weighed before and after injection into the vessel, to determine the mass of added sample. For N,N-Dimethylformamide a water content of $0.026 \%$ was obtained with a relative standard deviation of $14 \%$ (10 replicates). For acetone a water content of $1.08 \%$ was obtained with a relative standard deviation of $4 \%$ (9 replicates). These results confirm the good precision of the method, taking into consideration the low water content of the samples.

\section{- Carrying gas}

First, the water content of nitrogen as delivered was determined, connecting the gas directly to the measuring cell, at a pressure of $\operatorname{circa} 1.0 \mathrm{kPa} / \mathrm{cm}^{2}$, bubbling under the liquid surface of the catholyte. Initially nitrogen N45 was used, which had water contents of $400-500 \mu \mathrm{g} / \mathrm{min}$.

An attempt was made to reduce the water content of $\mathrm{N} 45$ by passing the gas through a washing flask with concentrated sulphuric acid, before entering the measuring unit. This reduced the water content to a level of circa $300 \mu \mathrm{g} / \mathrm{min}$, a value that is still too high.

Another quality of nitrogen, N60, was then used, with a water content as delivered of only circa $100 \mu \mathrm{g} / \mathrm{min}$.

Different drying agents were tested thereafter - silica gel, magnesium perchlorate and molecular sieves - either alone or in different combinations. The most efficient drying was obtained with the use of molecular sieves, particularly with pore size $1.0 \mathrm{~nm}$. This was the adopted drying system, producing bank experiments with values of $30-40$ $\mu \mathrm{g} / \mathrm{min}$.

For the actual experiments the $\mathrm{N}_{2}$ pressure was maintained at $1.5 \mathrm{kPa} / \mathrm{cm}^{2}$. For lower pressures the experiments take too long time, and for higher pressures the bubbling is tumultuous, giving rise to projections of the catholyte.

\section{Oven conditions}

The oven (figure 1) consists of a quartz tube, diameter $20 \mathrm{~mm}$ and length (in the hot zone) $12 \mathrm{~cm}$. The quartz tube is closed on both ends with circular metallic leads, clamped with an o-ring. The end closer to the operator has 2 holes, one for inlet and the other for the outlet of the carrier gas. The final arrangement of 1 and 2 for in and out gas was crucial for a good accuracy of the sample measurements, as the other arrangement produced big losses by water condensation on the cold zone, before entering the measuring vessel.

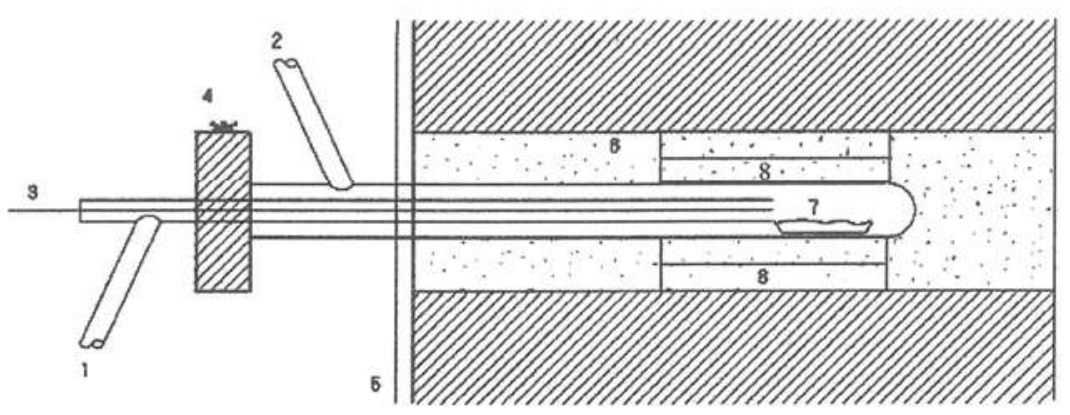

Figure 1. Tubular oven. 1 - outlet for $\mathrm{N}_{2} ; 2$ - inlet for $\mathrm{N}_{2} ; 3$ - Thermistor; 4 -O-ring; 5 -Oven wall; 6 - Refractive wall; 7 - sample holder; 8 - heating part of the oven

\section{- Direct Karl Fischer's titration of water in geologic samples}

Samples of mass $\sim 10-60 \mathrm{mg}$ were weighed in a weighing spoon, covered with parafilm, and added directly to the measuring vessel through one of its openings. The obtained mean water percentage values are presented in table 1 , together with the results of hygroscopic water $\left(\mathrm{H}_{2} \mathrm{O}^{-}\right)$and total water $\left(\mathrm{H}_{2} \mathrm{O}_{\text {total }}\right)$ obtained by the traditional methods used in Instituto Geológico Mineiro (IGM) for the same samples (the gravimetric method for $\mathrm{H}_{2} \mathrm{O}^{-}$and the Pennfield method for $\mathrm{H}_{2} \mathrm{O}_{\text {total }}$. 
Analysis of these values shows that, for most of the samples, the direct titration by Karl Fischer is not able to determine even the total amount of hygroscopic water, $\mathrm{H}_{2} \mathrm{O}$, i.e., the obtained values are much lower than the ones obtained by gravimetric analysis and the Penfield method. Nevertheless, for the samples identified as SD5, MSDb' and SD3B, which have low water contents (less than $0.5 \%$ ), the Karl Fisher's direct titration method seem to determine accurately the hygroscopic water content. A possible explanation of these results is that, as the samples do not dissolve in Karl Fischer's reagent, when the water content is high probably the solid-liquid interfacial contact is not enough to allow detection of the total amount of surface water.

Table 1 - Results of $\mathrm{H}_{2} \mathrm{O}^{-}$e $\mathrm{H}_{2} \mathrm{O}_{\text {total }}$ in geologic samples obtained by the traditional method and results of water \% obtained by Karl Fischer's method by direct titration.

\begin{tabular}{|c|c|c|c|}
\hline Sample & $\% \mathrm{H}_{2} \mathrm{O}^{-}$(a) & $\% \mathrm{H}_{2} \mathrm{O}_{\text {total }}$ (b) & $\% \mathrm{H}_{2} \mathrm{O}$ (K.F.) \\
\hline SD1 & 2.07 & 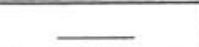 & 1.43 \\
\hline SD2 & 2.07 & 3.38 & 0.95 \\
\hline SD4 & 2.26 & 4.01 & 1.10 \\
\hline SD5 & 0.08 & 0.35 & 0.06 \\
\hline SD6 & 0.51 & 1.00 & 0.25 \\
\hline SD9A & 1.30 & 1.92 & 0.83 \\
\hline CHa4 & 0.47 & 4.51 & 0.82 \\
\hline MSDb' & 0.33 & 14.86 & 0.44 \\
\hline SD3B & 0.43 & 3.12 & 0.51 \\
\hline
\end{tabular}

(a) Gravimetric method; (b) Penfield method

\section{- Karl Fischer's titration of water in geologic samples with coupled oven}

The Karl Fischer's titration with coupled oven was tested at two different oven temperatures: $110^{\circ} \mathrm{C}$ e $950{ }^{\circ} \mathrm{C}$. These temperatures were chosen in analogy with the traditional methods for the determination of the two types of water $-110^{\circ} \mathrm{C}$ for the hygroscopic water and $950^{\circ} \mathrm{C}$ for the total water.

Each sample was weighed in a dried ceramics sample holder, and transferred quickly to the oven, which was already equilibrated at the desired temperature, with a constant flow of $\mathrm{N}_{2}$ which carried the liberated water to the measuring cell (see figure 2). At least 2 replicates were measured for each sample. The obtained results are presented in table

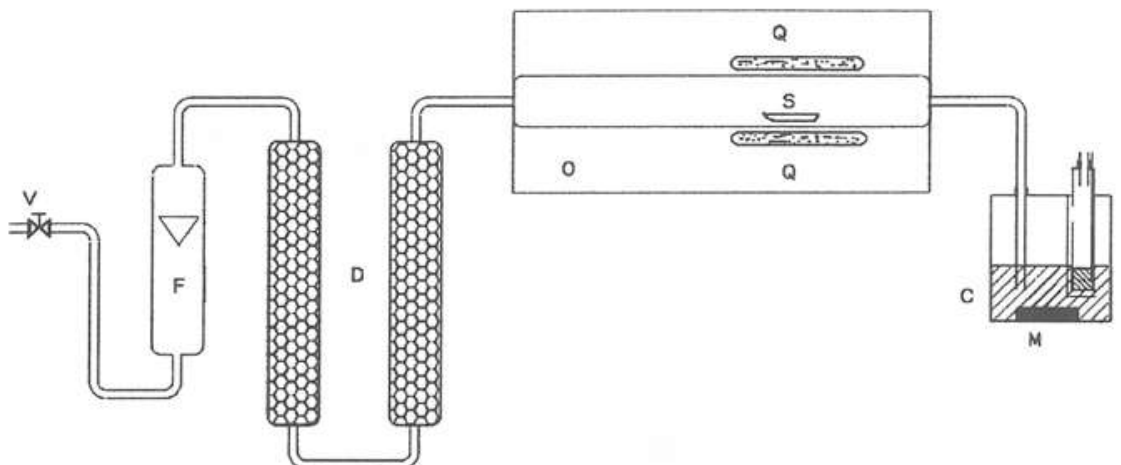

Figure 2. Scheme of the experimental set-up. V - valve for controlling $\mathrm{N}_{2}$ flux; $\mathrm{F}$ - flux measuring unit; $\mathrm{D}$-drying units; $\mathrm{S}$ - sample holder; $\mathrm{O}$ - oven; $\mathrm{Q}$ - heating part of the oven; $\mathrm{C}$ - coulometric titration cell; $\mathrm{M}$ - magnetic stirrer.

Table 2- Results of \% water content of geologic samples analysed by Karl Fischer's titration with coupled oven at $110^{\circ} \mathrm{C}$ and $950^{\circ} \mathrm{C}$.

\begin{tabular}{|c|c|c|c|c|c|c|}
\cline { 2 - 7 } \multicolumn{1}{c|}{} & \multicolumn{6}{c}{ Temperature of the oven $/{ }^{\circ} \mathbf{C}$} \\
\cline { 2 - 7 } \multicolumn{1}{c|}{} & \multicolumn{5}{c|}{$\mathbf{1 1 0}$} & \multicolumn{3}{c|}{950} \\
\hline Sample & $\mathbf{n}$ & $\mathbf{H}_{\mathbf{2}} \mathbf{O} \%$, mean & $\sigma$ & $\mathbf{n}$ & $\mathbf{H}_{\mathbf{2}} \mathbf{O} \%$, mean & $\sigma$ \\
\hline $\mathbf{2 4 0}$ & 9 & 2.35 & 0.20 & 3 & 7.47 & 0.21 \\
\hline $\mathbf{2 4 1}$ & 2 & 1.23 & 0.01 & 2 & 6.92 & 0.15 \\
\hline $\mathbf{2 4 2}$ & 4 & 0.45 & 0.09 & 4 & 4.40 & 0.34 \\
\hline $\mathbf{2 4 3}$ & 2 & 0.66 & 0.03 & 2 & 7.02 & 0.27 \\
\hline $\mathbf{2 4 4}$ & 2 & 0.72 & 0.03 & 2 & 6.53 & 0.25 \\
\hline $\mathbf{2 4 6}$ & ---- & --- & --- & 2 & 6.12 & 0.16 \\
\hline $\mathbf{2 5 2}$ & 3 & 0.60 & 0.07 & 3 & 6.09 & 0.22 \\
\hline $\mathbf{2 5 3}$ & 2 & 0.64 & 0 & 2 & 6.74 & 0.23 \\
\hline
\end{tabular}

$n=$ number of replicates

$\sigma=$ standard deviation (when $\mathrm{n} \geq 3$ ) or mean deviation (when $\mathrm{n}=2$ )

The same samples were analysed at IGM with the traditional methods - gravimetric method for $\mathrm{H}_{2} \mathrm{O}^{-}$and Penfield method for $\mathrm{H}_{2} \mathrm{O}_{\text {total }}$ - and also by the so called "loss on ignition" (measures the amount of volatile components). In table 3 we can see all these results for comparison. The results are plotted in figure 3, where the obtained differences can be more clearly seen.

In both cases (at $110^{\circ} \mathrm{C}$ e $950^{\circ} \mathrm{C}$ ) the Karl Fischer's method with coupled oven provided good results. The results present good repeatability and a good agreement with the 
values obtained by the traditional methods. This was very important as it showed that, on the contrary to the prior belief, the Penfield's method can determine with accuracy the total water in geologic samples. The present results, thus, served to validate this method.

Table 3 - Results obtained for $\mathrm{H}_{2} \mathrm{O}^{-}$e $\mathrm{H}_{2} \mathrm{O}_{\text {otal }}$ by Karl Fischer's method with coupled oven and by the traditional methods (gravimetric and Penfield) and results for the "loss on ignition" method.

\begin{tabular}{|c||c|c|c|c|c||}
\hline Sample & $\begin{array}{c}\% \mathrm{H}_{2} \mathrm{O}^{-} \\
(\mathrm{KF}) \text { Oven: } 110^{\circ} \mathrm{C}\end{array}$ & $\begin{array}{c}\% \mathrm{H}_{2} \mathrm{O} \\
(\mathrm{G} . \mathrm{M} .)\end{array}$ & $\begin{array}{c}\% \mathrm{H}_{2} \mathrm{O}_{\text {otal }} \\
\text { (KF) Oven: } 950^{\circ} \mathrm{C}\end{array}$ & $\begin{array}{c}\% \mathrm{H}_{2} \mathrm{O}_{\text {total }} \\
\text { (P.M.) }\end{array}$ & L.I.,\% \\
\hline $\mathbf{2 4 0}$ & 2.35 & 1.89 & 7.47 & 7.50 & 8.28 \\
\hline $\mathbf{2 4 1}$ & 1.23 & 1.24 & 6.92 & 6.80 & 6.72 \\
\hline $\mathbf{2 4 2}$ & 0.45 & 0.36 & 4.40 & 4.44 & 3.75 \\
\hline $\mathbf{2 4 3}$ & 0.66 & 0.43 & 7.02 & 7.22 & 5.39 \\
\hline $\mathbf{2 4 4}$ & 0.72 & 0.44 & 6.53 & 6.84 & 5.18 \\
\hline $\mathbf{2 4 6}$ & - & 2.05 & 6.12 & 6.25 & 8.24 \\
\hline $\mathbf{2 4 8}$ & 0.14 & 0.12 & - & 0.96 & 1.17 \\
\hline $\mathbf{2 5 2}$ & 0.60 & 0.52 & 6.09 & 6.44 & 5.10 \\
\hline $\mathbf{2 5 3}$ & 0.64 & 0.64 & 6.74 & 7.04 & 5.68 \\
\hline
\end{tabular}

Methods: K.F. - Karl Fischer; G.M - Gravimetric; P.M - Penfield; L.I. - Loss on Ignition

Figure 3. Comparison of the results obtained for $\mathrm{H}_{2} \mathrm{O}^{-}$and $\mathrm{H}_{2} \mathrm{Ot}_{\text {otal }}$ by the Karl Fischer's method with coupled oven and the traditional methods (gravimetric and Penfield), as well as "loss on ignition" results.

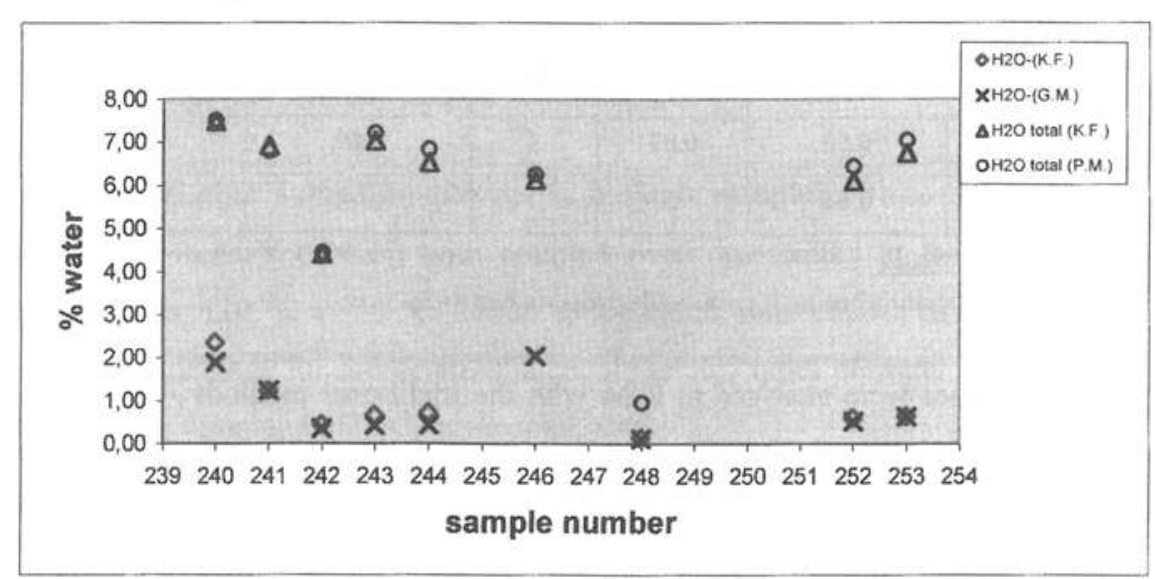

If we compare the values obtained with the "loss on ignition" method with the values for the total water, an incoherent result appears for some samples, namely, that some of these values are smaller than the total water. In order to try to understand this, each sample was analysed for its major elements. The obtained results are presented in table 4 , together with the values for $\mathrm{H}_{2} \mathrm{O}, \mathrm{H}_{2} \mathrm{O}_{\text {total }}$ and "loss on ignition". It can be seen that the samples that present lower values for "loss on ignition" than for $\mathrm{H}_{2} \mathrm{O}_{\text {total }}$ have a high $\mathrm{FeO}$ content, namely, samples $241,242,243,244,252$ and 253 . More, the highest the $\mathrm{FeO}$ concentration the largest is the difference.

Table 4 - Values for the major components (in \%) for the analysed geologic samples.

\begin{tabular}{|c|c|c|c|c|c|c|c|c|c|c|}
\hline Sample & 240 & 241 & 242 & 243 & 244 & 245 & 246 & 248 & 252 & 253 \\
\hline $\mathrm{SiO}_{2}$ & 68.57 & 67.44 & 69.75 & 52.56 & 52.67 & 42.35 & 79.41 & 78.54 & 58.60 & 54.36 \\
\hline $\mathrm{Al}_{2} \mathrm{O}_{3}$ & 10.29 & 12.42 & 8.45 & 13.87 & 13.69 & 14.71 & 10.98 & 12.36 & 12.91 & 13.02 \\
\hline $\mathrm{FeO}$ & 1.51 & 6.97 & 11.42 & 18.03 & 18.48 & 0.94 & 0.15 & 0.69 & 14.56 & 14.55 \\
\hline $\mathrm{MnO}$ & 0.03 & 0.05 & 0.09 & 0.15 & 0.14 & 0.04 & $<0.02$ & 0.05 & 0.12 & 0.13 \\
\hline $\mathrm{CaO}$ & $<0.04$ & $<0.04$ & $<0.04$ & $<0.04$ & $<0.04$ & $<0.04$ & $<0.04$ & 0.28 & $<0.04$ & $<0.04$ \\
\hline $\mathrm{MgO}$ & 1.01 & 1.87 & 2.37 & 4.12 & 3.16 & 0.35 & 0.05 & 0.11 & 3.64 & 3.70 \\
\hline $\mathrm{Na}_{2} \mathrm{O}$ & $<0.20$ & $<0.20$ & $<0.20$ & $<0.20$ & $<0.20$ & $<0.20$ & $<0.20$ & 4.90 & $<0.20$ & $<0.20$ \\
\hline $\mathrm{K}_{2} \mathrm{O}$ & 0.11 & 0.12 & $<0.03$ & $<0.03$ & $<0.03$ & $<0.03$ & 0.05 & 0.90 & $<0.03$ & $<0.03$ \\
\hline $\mathrm{TiO}_{2}$ & 0.12 & 0.12 & 0.29 & 0.57 & 0.59 & 0.74 & 0.12 & 0.04 & 0.53 & 0.56 \\
\hline $\mathrm{P}_{2} \mathrm{O}_{5}$ & $<0.03$ & $<0.03$ & $<0.03$ & 0.04 & $<0.03$ & 0.06 & $<0.03$ & $<0.03$ & $<0.03$ & 0.05 \\
\hline $\mathrm{H}_{2} \mathrm{O}_{\text {Total }}$ & 7.57 & 6.80 & 4.44 & 7.22 & 6.84 & 10.42 & 6.25 & 0.88 & 6.44 & 7.04 \\
\hline $\mathrm{H}_{2} \mathrm{O}^{-}$ & 1.89 & 1.25 & 0.36 & 0.43 & 0.44 & 2.18 & 2.05 & 0.12 & 0.52 & 0.60 \\
\hline L.I. & 8.28 & 6.72 & 3.75 & 5.39 & 5.18 & 11.11 & 8.24 & 1.17 & 5.10 & 5.68 \\
\hline L.I.- $\mathrm{H}_{2} \mathrm{O}_{\text {Total }}$ & +0.71 & -0.08 & -0.69 & -1.83 & -1.66 & +0.69 & +1.99 & +0.29 & -1.34 & -1.36 \\
\hline
\end{tabular}

An hypothesis to explain this situation is to consider that during the "loss on ignition" analysis an oxidation of $\mathrm{FeO}$ can occur, as it is done in a muffle, in a oxidan atmosphere. Fe would change its oxidation state from +2 to +3 , according to the reaction:

$$
2 \mathrm{FeO}+1 / 2 \mathrm{O}_{2} \rightarrow \mathrm{Fe}_{2} \mathrm{O}_{3}
$$

The consequence of this oxygen uptake in samples that contain $\mathrm{FeO}$ would be that the final value for the "loss on ignition" decreases proportionally to the $\mathrm{FeO}$ content, becoming smaller than the value for total water content. To confirm this hypothesis, a chemical study was performed in one of the samples (sample 252 - ref. MSDXXA). 
The obtained results showed that this is correct, i.e., the mass increase is actually due to oxidation of $\mathrm{FeO}$. Figure 4 shows that there is a very high correlation between the $\mathrm{FeO}$ content and the difference between the percentage values of the total water and "loss on ignition". Further, as far as the present results can show, it seems that for $\mathrm{FeO}$ contents bellow $6.5 \%$ (intercept) there will be no significant difference, i.e., the oxidation of $\mathrm{FeO}$ will not be significant and will not false the analysis result.

Figure 4. Samples with high $\mathrm{FeO}$ content. Plot of $\mathrm{FeO}$ content as a function of the observed difference between the values of total water and "loss on ignition".

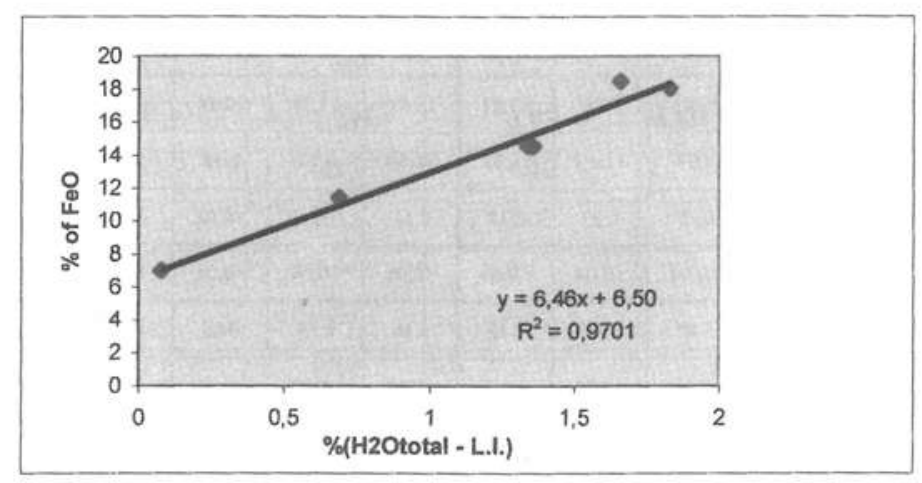

This was another very important result of the present study, as it showed that the geological meaning of the "loss on ignition" analysis - dehydration and loss of volatiles - is only valid in cases where it can be guaranteed that no oxidation reaction takes place, or at least not in a significant extent, and that extreme care must be taken on the analysis of such results, considering in each case the chemical nature of the sample.

\section{Conclusion}

The present work provides a new experimental set-up for water determination in geological samples, with a specially designed oven to be coupled to a normal Karl Fischer coulometer. It shows that reliable and reproducible results can be obtained with this method. Further, it allowed validation of the Penfield method, which is commonly used in geological analysis, and pointed out the extreme care that must be taken with results from the "loss on ignition" analysis.

\section{Acknowledgements}

Marta E. Themudo thanks Laboratório do Instituto Geológico Mineiro and Aquiles A. Barros and Margarida Bastos thank Fundação para a Ciência e a Tecnologia (C.I.Q.U.P.) for financial support.

\section{Bibliography}

1 - H. S. Washington, The chemical analysis of rocks, John Wiley \& Sons, Inc., New York, 1930 .

2 - J. Mitchell, D. M. Smith, Aquametry, $2^{\text {nd }}$ ed., Interscience, New York, 1977.

3 - F. Sherman, I. Kuselman, "Stoichiometry and chemical metrology: Karl Fischer reaction". Accred. Qual. Assu., Springer-verlag, 1994, 4, 230.

4 -A.I. Vogel, A text book of quantitative inorganic analysis, $3^{\text {rd }}$ ed, Longmans.

5 - B. P. Atkin and C. Somerfield, "The determination of total sulphur in geological materials by coulometric titration", Chemical Geology, Elsevier Science B. V., Amsterdam,1994, 131-134.

6 - Van Erem et al, "Determination of water in forages and animal feeds by Karl Fischer titration", Journal of AOAC International, Vol 81, No 1,1998.

7 -R. C. Graça and R.D.dos Santos, "Determinação de $\mathrm{OH}^{+}$em amostras de rochas, por potenciometria, utilizando a solução de Karl Fischer”, Bol. Mus.Lab.Min.Geol. Faculdade de Ciências de Lisboa,1979, 16, 151-160.

8 - K.Yamaya, "Determination of the Water content in muscovites containing large amounts of fluorine by Karl Fischer titration after fusion with silicon dioxide", Analytica Chimica Acta,1979, 110, 233-243.

9 - C. Cipriani and G. Bernardini, "Research in geochemical methodology, VII: Determination of water by titration with Karl Fischer reagent". Atti. Soc. Toscana sci. Nat. Pisa, Mem. P V., Ser. A, 65, pp.221-236. 